Uşak Üniversitesi Sosyal Bilimler Dergisi

$2015,8 / 3$

\title{
TMS 29 Yüksek Enflasyonlu Ekonomilerde Finansal Raporlama Standardı Çerçevesinde Finansal Tabloların Düzeltilmesi ve Finansal Analiz Sonuçları Üzerine Etkileri
}

Dursun KELEŞ*

\section{Öz}

Finansal tablolar, işletmelerin finansal durumunu ve faaliyet sonuçlarını yansıtan araçlardır. Yüksek enflasyonlu dönemlerde işletmelerin hazırlamış oldukları finansal tablolar gerçek finansal durumu ve faaliyet sonuçlarını yansıtmamaktadır. Bunun nedeni, enflasyon olarak ifade edilen fiyatlar genel seviyesinde yaşanan artışlardır. Yüksek enflasyonlu dönemlerde gerçek sonuçlara ulaşabilmek için finansal tabloların enflasyonun olumsuz etkisinden arındırılması gerekmektedir. Finansal tablolar üzerindeki enflasyonun etkilerini gidermeye yönelik bazı yöntemler kullanılmaktadır. Bu yöntemler, fiyatlar genel seviyesi muhasebesi, cari maliyet muhasebesi ve genel fiyat-cari maliyet muhasebesi yöntemleridir. $\mathrm{Bu}$ çalışmada, enflasyonun etkilerini gidermeye yönelik yöntemler incelenmiş ve TMS 29: Yüksek Enflasyonlu Ekonomilerde Finansal Raporlama Standardı çerçevesinde finansal tablolar düzeltilerek, düzeltme neticesi ortaya çıkan sonuçların işletme ve finansal analiz üzerine etkileri ortaya konulmuştur.

Anahtar Kelimeler: TMS 29, Enflasyon Muhasebesi, Fiyatlar Genel Seviyesi Muhasebesi.

Correction of the Financial Statements within the Scope of TAS 29: Financial Reporting Standard in Hyperinflationary Economies and Its Effects on Financial Analysis Results

\begin{abstract}
Financial statements are instruments reflecting the financial position and operating results of companies. Financial statements that companies make up in high inflation period do not reflect the real financial position and operating results. This is because prices stated as inflation are increases at general price level. In order to reach the real results in high inflation periods, it is required to clarify the financial statements from negative effects of the

* Doktora Öğrencisi, Niğde Üniversitesi Sosyal Bilimler Enstitüsü İşletme Anabilim Dalı Muhasebe ve Finansman Bilim Dalı
\end{abstract}


inflation. Some methods are being used for eliminating the effects of inflation on financial statements. These methods are the methods of general price level accounting, current cost accounting and general price-current cost accounting. In this study, the methods aimed at eliminating the effects of inflation were analyzed and the financial statements were corrected within the scope of TAS 29: Financial Reporting Standard in Hyperinflationary Economies and then the effects of results from the correction on company and financial analysis were revealed.

Key Words: TAS 29, Inflation Accounting, General Price Level Accounting.

\section{Giriş}

Fiyatlar genel seviyesindeki artış olarak ifade edilen enflasyonun işletmelerin varlık ve kaynakları ile finansal analiz sonuçları üzerinde önemli etkileri bulunmaktadır. Enflasyonun paranın satın alma gücü üzerindeki olumsuz etkileri nedeniyle finansal tabloların işletmenin finansal durumunu gerçeğe uygun olarak yansitmasina engel olmaktadır. Enflasyonun etkileri dikkate alınmadan hazırlanan finansal tablolar yanıltıcı bilgiler sundukları için finansal bilgi kullanıcılarının da yanlış yönlendirilmelerine neden olmaktadır. Bundan dolayı enflasyonun finansal tablolar üzerindeki bozucu etkilerinin ortadan kaldırılması gerekmektedir. Enflasyonun olumsuz etkilerinin giderilmesine yönelik vergi mevzuatında bir takım kısmi düzeltme yöntemleri bulunmaktadır. Ancak bu kısmi düzeltme yöntemleri, uzun süren ve yüksek düzeyde gerçekleşen enflasyon nedeniyle yetersiz olmaktadır. Bundan dolayı enflasyonun olumsuz etkilerinin ortadan kaldırılması amacıyla enflasyon muhasebesi yöntemleri devreye konulmuştur.

$\mathrm{Bu}$ çalışmada, enflasyon muhasebesi yöntemleri hakkında bilgiler verilerek, TMS 29 Yüksek Enflasyonlu Ekonomilerde Finansal Raporlama Standardının da önermiş olduğu Fiyatlar Genel Seviyesi Muhasebesi yöntemi uygulamalı olarak incelenmektedir.

\section{Enflasyon Kavramı}

Enflasyon, fiyatlar genel seviyesindeki sürekli bir artışın yanında, paranın değerindeki sürekli bir azalışı ifade etmektedir. Buna göre bir malın değerindeki azalış sadece o malı üreten ve satanları etkilememekte, bunun yanı sıra toplumun bütün kesimini de olumsuz yönde etkilemektedir (Osman, 1995: 1). 
Sosyal Bilimler Dergisi 33

Klasik iktisatçılar enflasyonu, para yaratan otoritenin kamu harcamalarının kamu gelirlerinden fazla olması sonucunda meydana gelen bütçe açılarının kapatılması için piyasadaki para emisyonunu artırması olarak tanımlamıştır. Bu tanıma karşılık Keynesyen iktisatçılar enflasyonun toplam arz düzeyinin toplam talep düzeyinden düşük kalması sonucunda ortaya çıktığını ileri sürerek, enflasyonun sebebi olarak para arzını ortaya koyan klasik iktisatçıların görüşüne karşı çıkmışlardır (Kaygusuz, 2001: 1).

\section{Enflasyonun Finansal Tablolar Üzerindeki Etkileri}

Finansal tablolar, işletmelerin varlık ve kaynaklarında ortaya çıkan değişimler sonucu oluşan finansal durum ile gelir ve giderlerinde oluşan değişimler neticesi ortaya çıkan faaliyet sonuçlarının toplu halde gösterildiği araçlardır.

Finansal tabloların amacl; kredi verenler, yatırımcılar, işletme yöneticileri ve diğer ilgililer için gerçeğe uygun bilgi sağlamak, gelecekteki nakit akışlarının değerlendirilmesine yardımcı olmak ve işletmenin finansal durumu ve faaliyet sonuçları hakkında bilgi sunmaktır.

Yüksek enflasyonlu ortamda faaliyet gösteren işletmeler, varlık ve kaynaklarını reel olarak tespit edememektedir. Bunun sonucunda işletmeyle ilgisi bulunan menfaat gruplarına da yanlış ve yanıltıcı bilgiler sunulabilmektedir. Finansal tablolar üzerindeki yüksek enflasyonun olumsuz etkisi, tarihi değerleri dikkate alan geleneksel muhasebe ile düzenlenen finansal tabloların enflasyon nedeniyle reel değerleri yansitamamasından kaynaklanmaktadır. Tarihi maliyetleri dikkate alan geleneksel muhasebe anlayışı, özel fiyat hareketleri kadar genel fiyat düzeyindeki değişiklikleri de dikkate almaması ve dolayısıyla bu değişikliklerin finansal tablolarda gösterilmemesi nedeniyle finansal bilgi kullanıcılarının beklentilerine cevap verememektedir (Aktaş, 2006: 16).

\subsection{Enflasyonun Bilanço Üzerindeki Etkileri}

Enflasyonun neden olduğu genel fiyat düzeyindeki artışlar bütün bilanço kalemlerini aynı düzeyde etkilememektedir. Bilanço kalemleri yüksek enflasyondan etkilenme şekillerine göre parasal olan kalemler ve parasal olmayan kalemler olarak iki şekilde sınıflandırılmaktadır.

Parasal kalemleri, varlık ve kaynaklar açısından incelemek konunun anlaşılması açısından daha sağlıklı olacaktır. Parasal varlık kalemleri, para değerindeki değişimlere rağmen nominal değerleri değişmeyen ancak satın alma güçlerinde değişme yaşanan kalemlerdir. Başka bir ifadeyle fiyat hareketleri ne olursa olsun nominal tutarları sabit kalırken satın alma güçleri azalan kalemlerdir. Parasal varlık kalemlerine örnek olarak; kasa, banka, 
alacak senetleri, alacaklar, tahviller, verilen depozito ve teminatlar gibi kalemler gösterilebilmektedir (Yavuz, 2007: 31-32).

Enflasyonun parasal kalemler üzerinde satın alma gücünü azaltıcı etkisi bulunduğundan, parasal varlıkları fazla olan işletmelerde satın alma gücü kaybı yaşanmakta ve bunun sonucunda zarar edilmektedir (Akdoğan ve Tenker, 2001: 690).

Parasal kaynak kalemleri de para değerindeki değişimler karşısında nominal değerlerini aynen koruyan kalemlerdir. Ancak varlıkların tersine enflasyon ortaminda fiyatlar genel seviyesi yükselirken borç yükünde azalma olmaktadır. Böylece işletmenin özsermayesinde artış meydana gelmektedir (Yavuz, 2007: 32).

Parasal olmayan kalemlerini de varlık ve kaynaklar açısından incelemek konunun anlaşılması açısından daha sağlıklı olacaktır. Parasal olmayan varlık kalemleri, para değerindeki değişime rağmen satın alma güçleri değişmeyen ancak nominal değerlerinde değişim yaşanan kalemlerdir. Parasal olmayan varlık kalemlerine örnek olarak; stoklar, hisse senetleri, maddi duran varlıklar, gelecek dönemlere ilişkin giderler gibi kalemler gösterilebilmektedir (Akdoğan ve Tenker, 2001: 689).

Parasal olmayan kaynak kalemleri ise, para değerindeki değişimler karşısında nominal değerleri değişen kalemlerdir. Parasal olmayan kaynak kalemlerine, gelecek dönemlere ait gelirler, yabancı parayla ödenecek borçlar, alınan avanslar gibi kalemler örnek olarak gösterilebilmektedir (Yavuz, 2007: 33).

\subsection{Enflasyonun Gelir Tablosu Üzerindeki Etkileri}

İşletmenin faaliyet dönemine ilişkin gelir ve gider kalemlerinden oluşan tabloya gelir tablosu adı verilmektedir. Gelir tablosu unsurlarının tamamı parasal olmayan kalemlerden meydana geldiğinden, her bir kalemin ilk işlem tarihindeki düzeltme katsayısı ile düzeltilmesi gerekmektedir (Aktaş, 2006: 26).

Gelir tablosunda satışlar, ücretler, faizler enflasyonu yansıtmaktadır. Buna karşlık amortismanlar duran varlıkların edinildikleri tarihteki maliyet değerleri üzerinden ayrıldığı için enflasyonu yansıtmamaktadır. Satışların maliyeti kaleminin ise enflasyonun muhtemel etkilerini göstermesi, uygulanan stok değerleme yöntemlerine göre değişiklik göstermektedir. Stok değerleme yöntemlerinden ilk giren-ilk çıkar yöntemi cari maliyetleri yansıtmaması nedeniyle enflasyonun etkilerini doğru bir şekilde göstermemektedir. Son giren-ilk çıkar yöntemi ise cari maliyetleri daha yakından takip etmesi sebebiyle enflasyonun etkisini yansıtmaktadır (Çelik, 2003: 17). 
Sosyal Bilimler Dergisi 35

Gelir tablosunda yer alan satışların maliyeti ve amortisman kalemlerinin enflasyona göre düzeltilmeleri durumunda vergi öncesi karın daha düşük tutarda ortaya çıkması muhtemeldir. Enflasyona göre düzeltme işlemi yapılmayan finansal tablolarda vergi öncesi hesaplanan kâr üzerinden ödenen vergiler, olması gereken tutardan daha yüksek hesaplanmakta ve bu ödemeler nakit akışının negatif yönde bir seyir izlemesine neden olmaktadır. Dolayısıyla düzeltme işlemi yapılmamış gelir tablolarında net kâr olması gerekenden daha yüksek görüneceğinden yanlış kararlar alınmasına neden olabilmektedir. Ayrıca dağıtılan kâr payları da olması gereken tutardan daha yüksek seviyede olacağından işletme bu durumda gerçek kârını değil, elindeki sermayeyi dağıtmış olacaktır (Çelik, 2003: 17).

\section{Enflasyon Muhasebesi}

Finansal tabloların enflasyonun neden olduğu yıkıcı etkilerden arındırılması işlemleri genel itibariyle enflasyon muhasebesi ismiyle ifade edilmektedir (Çabuk ve Lazol, 2013: 297).

Sürekli değişimler gösteren fiyatlar karşısında paranın satın alma gücünü göz ardı eden geleneksel muhasebe uygulamaları dikkate alınarak ortaya konan bilgiler enflasyonun etkilerini giderici kısmi düzeltme yöntemleriyle düzeltilmeye çalışılsa dahi, yine de finansal tablolar önemli düzeyde yanıltıcı bilgiler sunabilmektedir. $\mathrm{Bu}$ durum işletmelerin sürekliliğine yönelik alınacak kararların doğruluğunu azaltacağı gibi bilgi kullanıcılarının yanıltılmasına da neden olabilmektedir. Bundan dolayı enflasyonun yüksek seyrettiği dönemlerde muhasebenin gerçeğe uygun bilgi ortaya koyabilmesi için geleneksel muhasebe anlayışıyla düzenlenen finansal tabloların enflasyona göre değiştirilmesini sağlayan enflasyon muhasebesi yöntemlerinin uygulanmasına gereksinim duyulmaktadır (Özulucan, 2002a: 129).

Enflasyon muhasebesi, muhasebe kayttlarında herhangi bir değişiklik yapılmasını öngören bir yöntem değildir. Enflasyon muhasebesi en genel hatlarıyla işletmenin finansal tablolarının enflasyon karşısında güncellenmesini, başka bir ifadeyle çeşitli endeksler yardımıyla düzeltilmesini öngörmektedir. Kullanılacak ölçü birimi olarak ise paranın nominal değerinden ziyade, satın alma gücünü dikkate almaktadır (Uslu, 2003: 1).

Enflasyon muhasebesi, parasal olmayan finansal tablo kalemlerinin enflasyona göre düzeltme işleminde dikkate alınacak tutarlarının düzeltme katsayısıyla çarpılması suretiyle finansal tabloların hazırlandığı tarihteki satın alma gücü üzerinden hesaplanmasını sağlamaktadır (Altınışık, 2004: 133). 


\subsection{Enflasyon Muhasebesi Yöntemleri}

Genel düzeltme yöntemlerini konu alan enflasyon muhasebesi yöntemleri üç şekilde sınıflandırılmaktadır. Bunlar (Çabuk ve Lazol, 2013: 299);

- Fiyatlar Genel Seviyesi Muhasebesi Yöntemi

- Cari Maliyet Muhasebesi Yöntemi

- Genel Fiyat Cari Maliyet Muhasebesi Yöntemi

$\mathrm{Bu}$ yöntemler, tarihi maliyetleri dikkate alan geleneksel muhasebenin önermiş olduğu kısmi düzeltme yöntemlerinin yüksek enflasyonlu dönemlerde yetersiz kalması nedeniyle ortaya çıkmış ve uygulamaya konulmuştur.

\subsubsection{Fiyatlar Genel Seviyesi Muhasebesi Yöntemi}

Fiyatlar genel seviyesi muhasebesi, yüksek enflasyonlu dönemlerde fiyatlar genel seviyesindeki değişimlerin finansal tablolara olan olumsuz etkilerini gidermek üzere, finansal tablo kalemlerinin fiyat genel endeksleri yardımıyla düzeltilerek, finansal tabloların düzenlenmiş oldukları tarihteki paranın satın alma gücü açısından ifade edilmesini sağlamaktadır (İleri ve Altınışık, 2004: 42).

Fiyatlar genel seviyesi muhasebesi uygulanırken bilançonun bütün kalemleri paranın satın alma gücüne göre ifade edilerek cari değerle gösterilmeleri sağlanmalıdır. Bu yöntemin uygulanmasında dönem başı ve dönem sonu finansal tabloları kullanılmaktadır. Öncelikle, bilanço kalemleri parasal kalemler ve parasal olmayan kalemler olmak üzere iki şekilde sınıflandırılmaktadır. Bilanço kalemlerinden nakit veya nakit benzerleriyle tahsil edilecek ve ödenecek parasal varlık ve kaynak kalemleri enflasyon ortamında gerçeği yansıttıkları için düzeltme işlemine tabi tutulmamaktadır. Parasal olmayan kalemler ise satın alma tarihleri dikkate alınarak düzeltilmektedir. Bunun yanında, faaliyet dönemi süresince parasal varlıkları elde bulundurmaktan doğan enflasyon kayıpları ile parasal borçları elde bulundurmaktan doğan enflasyon kazancı da gelir veya gider unsuru olarak gelir tablosunda gösterilmektedir (Çelik, 2003: 31).

$\mathrm{Bu}$ yöntemde, enflasyonun genel düzeyini ölçmek için güvenilir endeksler olarak ifade edilen milli gelir deflatörü, Tüketici Fiyatları Genel Endeksi (TÜFE) ve Toptan Eşya Fiyat Endeksi (TEFE) kullanılabilmektedir. Seçilen bu endekslerden biri yardımıyla finansal tablo kalemleri düzeltilmektedir. 


\subsubsection{Cari Maliyet Muhasebesi Yöntemi}

Fiyatlar genel seviyesinde yaşanan artışın bütün mal ve hizmetlerde aynı düzeyde ortaya çıkmadığını ifade eden bu yöntem, fiyatlar genel seviyesi muhasebesinin finansal tablo kalemlerine ait özel fiyat değişimlerini istenilen düzeyde gideremediğini ifade etmektedir. Bundan dolayı yüksek düzeyde seyreden enflasyonun işletme üzerindeki olumsuz etkilerinin ortadan kaldırılmasına yönelik bu yöntemden faydalanılması gerekmektedir (Özulucan, 2002a:131). Bu yöntemde fiyatlar genel seviyesi muhasebesinden farklı olarak sermayenin üretim gücünü korumak esastır (Özdemir ve Arslan, 2007: 94).

\subsubsection{Genel Fiyat-Cari Maliyet Muhasebesi Yöntemi}

Genel Fiyat Cari Maliyet Muhasebesi, hem fiyatlar genel seviyesi endeksi hem de cari değer esasına göre düzeltme yöntemlerinin birleştirilmesiyle ortaya çıkan bir düzeltme yöntemidir. Bu yöntemin esasını, endekslere göre düzeltme işlemi teşkil etmektedir. Ancak endeks esasına göre düzeltme yapılırken düzeltme sırasındaki kalemlerin değeri de dikkate alınmaktadır. Cari değer esası, endeks esasını kontrol etmekte ve uygulanmasını sağlamaktadır (Çabuk ve Lazol, 2013: 301).

4. TMS 29 Yüksek Enflasyonlu Ekonomilerde Finansal Raporlama Standardı Çerçevesinde Enflasyon Muhasebesi Uygulaması

Enflasyonun yüksek düzeyde seyrettiği bir ekonomide işletmenin faaliyet sonuçlarının ve finansal durumunun, enflasyona göre düzeltme işlemi yapılmaksızın ulusal para birimine göre raporlanması doğru ve güvenilir bilgilerin sunulmasına engel teşkil etmektedir. Paranın satın alma gücünü kaybetmesi nedeniyle değişik dönemlerde ortaya çıkan işlemlerin tutarlarının karşılaştırılması dahi aynı hesap dönemi içerisinde mümkün olmayabilmektedir (TMS 29, Paragraf 2). Bu nedenle enflasyonun yüksek olduğu dönemlerde gerekli düzeltmelerin yapılması gerekmektedir. Bu düzeltmelerin nasıl yapılacağına ilişkin ilke ve kurallar TMS 29 Yüksek Enflasyonlu Ekonomilerde Finansal Raporlama Standardında düzenlenmiştir.

\subsection{Standardın Kapsamı}

TMS 29, işletmelerin enflasyonun yüksek olduğu bir ekonominin para birimi üzerinden düzenlemiş oldukları bütün temel finansal tablolara 
(konsolide finansal tablolar dahil) uygulanmak durumundadır. TMS 29, enflasyonun yüksekliğine ilişkin net bir oran belirtmemektedir. Finansal tabloların bu standart kapsamında ne zaman düzeltilmesi gerekeceği işletmelerin takdirine bırakılmıştır (TMS 29, Paragraf: 2-3).

Yüksek enflasyon koşulları, TMS29 Yüksek Enflasyonlu Ekonomilerde Finansal Raporlama Standardında aşağıdaki gibi siralanmaktadır (TMS 29, Paragraf: 3).

i- Nüfusun büyük bir bölümü tasarruflarını parasal olmayan varlıklarda veya yabancı para biriminde tutarak değerlendirmektedir. Tasarruf edilen ulusal para, satın alma gücünü korumak amacıyla kısa sürede yatırıma çevirme vb. suretiyle değerlendirilmektedir.

ii- Nüfusun büyük bir bölümü parasal değerleri ulusal para birimi üzerinden değil, daha ziyade istikrarlı bir döviz birimi üzerinden dikkate almaktadır. Fiyatlar da bu döviz birimi üzerinden tespit edilmektedir.

iii- Kredili olarak yapılan satışlar ile satın alımlarda ortaya çıkan fiyatlar; kısa bir süre olsa dahi, kredi süresince satın alma gücünde ortaya çıkması tahmin edilen zararları karşılayacak seviyede tespit edilmektedir.

iv- Ücretler, faiz oranları ve fiyatlar bir fiyat endeksine bağlıdır.

v- Son üç yılda ortaya çıkan kümülatif enflasyon oranı \%100'e yakın ya da bu oranın üzerinde gerçekleşmektedir.

Yüksek enflasyonlu dönemlerde ulusal paranın satın alma gücü sürekli bir azalış eğilimine girmektedir. Farklı satın alma güçleriyle ifade edilen varlıklar nedeniyle faaliyet sonuçları ve finansal durumu gösteren finansal tabloların enflasyona göre düzeltilmemesi durumunda bilgi kullanıcılarının yanlış kararlar almalarına neden olunabilmektedir (Özulucan, 2002b: 29-30).

TMS 29'da finansal tabloların düzeltilmesinde satın alma gücünde ortaya çıkan değişiklikleri gösteren genel bir fiyat endeksinin kullanılması gerektiği ifade edilmektedir (TMS 29, Paragraf: 37). TMS 29 standardının da ifade ettiği şekilde yüksek enflasyonlu ortamlarda finansal tabloların uygun bir endeks yardımıyla enflasyon muhasebesi yöntemlerinden fiyatlar genel seviyesi muhasebesine göre düzeltilmesi gerekmektedir.

\subsection{Fiyatlar Genel Seviyesi Muhasebesine Göre Finansal Tabloların Düzeltilmesi}

Fiyatlar genel seviyesi muhasebesi fiyat genel değişimlerinin finansal tablolarda yarattığ olumsuz etkileri ortadan kaldırmak ve fiyat değişimlerinin işletmenin iktisadi koşullarında ortaya çıkardığ 1 değişimi belirlemek için finansal tablo kalemlerinin genel fiyat endeksleri kullanılarak düzeltilmesi gerektiğini ifade eden bir yöntemdir (Gücenme, 1996: 61). 
Sosyal Bilimler Dergisi 39

Fiyatlar genel seviyesi muhasebesinin amacı, enflasyon nedeniyle güvenilirliğini kaybeden ve gerçeğe uygun bilgi sunumundan oldukça uzaklaşan finansal tablo kalemlerini aynı satın alma gücüne sahip para birimi üzerinden göstererek güvenilir hale getirmek, gelir ve giderleri cari para tutarları üzerinden göstererek faaliyet karının gerçek durumunu ortaya koymak ve parasal kalemleri elde tutmaktan dolayı işletmelerin karşı karşıya kaldığı enflasyon kazanç veya kayıplarını ortaya koymaktır (Açık, 2006: 353).

Fiyatlar genel seviyesi muhasebesine göre enflasyon düzeltmesi yapılırken, istenilen hedeflere ulaşılabilmesi amacıyla aşağıda sıralanan adımların gerçekleştirilmesi gerekmektedir (Yüksel, 1997: 45-50).

Birinci Adım: Tarihi maliyetler üzerinden hazırlanan son iki yıla ait finansal tabloların temin edilerek, kullanılacak düzeltme endeksinin tespit edilmesi ve buna göre düzeltme katsayılarının belirlenmesi,

İkinci Adım: Parasal olan ve parasal olmayan varlık ve borç kalemlerinin tespit edilmesi,

Üçüncü Adım: Cari yıla ait bütün parasal olmayan tutarların incelenmesi ve bunların aktifleştirildiği tarihlerin tespit edilmesi,

Dördüncü Adım: Cari yıla ait gelir tablosunda yer alan gelir, gider, dağıtılan ve dağıtılmamış kardaki değişimler incelenerek, bu değişimlerin ne zaman meydana geldiğinin ve sonuca dâhil edildiğinin tespit edilmesi,

Beşinci Adım: Parasal olmayan kalemlerin cari para birimi üzerinden düzeltilmesi,

Altıncı Adım: Dönem başı bilançosunda yer alan parasal tutarların cari para birimi üzerinden gösterilmesi,

Yedinci Adım: Parasal olmayan kalemlerin cari para birimi üzerinden ifade edilmesinin ardından "düzeltilmiş maliyet veya cari maliyet değerinden küçük tutarda olanıyla değerleme" kuralının dikkate alınması,

Sekizinci Adım: Parasal kalemlere ilişkin değerleri elde tutmaktan kaynaklanan enflasyon kayıp veya kazancının tespit edilmesi,

Dokuzuncu Adım: Bir önceki yıla ait düzeltilmiş finansal tabloların cari yılın satın alma gücü tutarı üzerinden gösterilmesi.

Fiyatlar genel seviyesi muhasebesinde varlıklar ve borçlar öncelikle parasal ve parasal olmayan kalemler olarak ayrıma tabi tutulmaktadır. Nakit ve nakitle tahsil edilecek ve ödenecek kalemler olarak ifade edilen parasal kalemler enflasyona göre düzeltilmemektedir. Bunun nedeni, parasal varlıkların geleneksel muhasebe anlayışıyla düzenlenen finansal tablolarda cari satın alma gücü ile yer almakta olmalarıdır (Özulucan, 2002b: 30-31 ).

$\mathrm{Bu}$ yöntemde endeks yardımı ile düzeltilmesi gereken kalemler, tarihi değerleri cari değerlerinden farklı olan stoklar, maddi duran varlıklar, 
hisse senetleri vb. parasal olmayan kalemlerdir. Bu bölümde, bir işletmenin finansal tablolarının enflasyonist dönemde bulunulduğu varsayımılla TMS 29 'un önerdiği fiyatlar genel seviyesi muhasebesine göre düzeltilmesine ilişkin örnek uygulama yapılmaktadır.

Uygulamalı Örnek: XYZ İşletmesinin 2013 yılına ilişkin dönem başı ve dönem sonu bilançosu aşağıdaki gibidir.

Tablo 1. XYZ İşletmesinin Dönem Başı ve Dönem Sonu Bilançoları

\begin{tabular}{|l|r|l|r|}
\hline \multicolumn{1}{|c|}{$\begin{array}{l}\text { 01.01.2013 Tarihli Dönem Başı } \\
\text { Bilançosu }\end{array}$} & \multicolumn{1}{c|}{$\begin{array}{c}\text { 31.12.2013 Tarihli Dönem Sonu } \\
\text { Bilançosu }\end{array}$} \\
\hline $\begin{array}{l}\text { 1.DÖNEN } \\
\text { VARLIKLAR }\end{array}$ & $\mathbf{2 4 0 . 0 0 0}$ & $\begin{array}{l}\text { 1.DÖNEN } \\
\text { VARLIKLAR }\end{array}$ & $\mathbf{2 3 0 . 0 0 0}$ \\
\hline A. Hazır Değerler & $\mathbf{2 1 0 . 0 0 0}$ & A. Hazır Değerler & $\mathbf{2 2 0 . 0 0 0}$ \\
\hline Kasa & 100.000 & Kasa & 70.000 \\
\hline Alınan Çekler & 10.000 & Alınan Çekler & 30.000 \\
\hline Bankalar & 100.000 & Bankalar & 120.000 \\
\hline E. Stoklar & $\mathbf{3 0 . 0 0 0}$ & E. Stoklar & $\mathbf{1 0 . 0 0 0}$ \\
\hline Ticari Mallar & 30.000 & Ticari Mallar & 10.000 \\
\hline $\begin{array}{l}\text { 2.DURAN } \\
\text { VARLIKLAR }\end{array}$ & $\mathbf{1 1 0 . 0 0 0}$ & $\begin{array}{l}\text { 2.DURAN } \\
\text { VARLIKLAR }\end{array}$ & $\mathbf{8 0 . 0 0 0}$ \\
\hline $\begin{array}{l}\text { D. Maddi Duran } \\
\text { Varlıklar }\end{array}$ & $\mathbf{1 1 0 . 0 0 0}$ & $\begin{array}{l}\text { D. Maddi Duran } \\
\text { Varlıklar }\end{array}$ & $\mathbf{8 0 . 0 0 0}$ \\
\hline Binalar & 50.000 & Binalar & 50.000 \\
\hline $\begin{array}{l}\text { Tesis Makine } \\
\text { Cihazlar }\end{array}$ & 50.000 & $\begin{array}{l}\text { Tesis, Makine ve } \\
\text { Cihazlar }\end{array}$ & 50.000 \\
\hline Taşıtlar & 10.000 & Taşıtlar & 10.000 \\
\hline & $\mathbf{3 5 0 . 0 0 0}$ & Birikmiş Amortisman (-) & $(30.000)$ \\
\hline AKTİF TOPLAMI & $\mathbf{1 0 0 . 0 0 0}$ & $\begin{array}{l}\text { 1. KISA VAD.YAB. } \\
\text { KAY. }\end{array}$ & $\mathbf{3 1 0 . 0 0 0}$ \\
\hline $\begin{array}{l}\text { 1. KISA VAD.YAB. } \\
\text { KAY. }\end{array}$ & $\mathbf{1 0 0 . 0 0 0}$ & A. Mali Borçlar & $\mathbf{8 0 . 0 0 0}$ \\
\hline A. Mali Borçlar & 100.000 & Banka Kredileri & 80.000 \\
\hline Banka Kredileri & $\mathbf{2 5 0 . 0 0 0}$ & $\mathbf{3 . O ̈ Z K A Y N A K L A R ~}$ & $\mathbf{2 3 0 . 0 0 0}$ \\
\hline 3.ÖZKAYNAKLAR & 250.000 & Sermaye & $\mathbf{2 0 0 . 0 0 0}$ \\
\hline Sermaye & $\mathbf{3 5 0 . 0 0 0}$ & Pönem Karı & $\mathbf{3 0 . 0 0 0}$ \\
\hline & & $\mathbf{3 1 0 . 0 0 0}$ \\
\hline PASİF TOPLAMI TOPLAMI & \\
\hline
\end{tabular}

XYZ İşletmesi 31.12.2013 tarihli bilançoya göre 30.000TL kar elde etmiştir. TEFE'den yararlanılarak parasal olmayan bilanço kalemleri fiyatlar 
genel seviyesi muhasebesine göre düzeltilmiştir. Parasal kalemler ise düzeltilmeyeceğinden aynı tutarları üzerinden yer almıştır. TEFE'ye ilişkin veriler, Türkiye İstatistik Kurumu (TÜIK) tarafından yayınlanmakta olup, düzeltme işlemlerinde bu verilerden yararlanılmıştır.

TÜIK tarafından yayınlanan İstatistiksel Tablolar arasında yer alan TEFE verilerinin bulunduğu tabloya göre; 2013 yılı Aralık ayında TEFE 16.081,9 iken, 2012 yılı Aralık ayında 15.033,81 olarak gerçekleşmiştir (http://www.tuik.gov.tr/PreTablo.do?alt id=1076). Düzeltme işlemleri sırasında parasal olmayan kalemlerin 2012 yılı Aralık ayında aktifleştirildiği varsayılarak 2012 yılı sonundaki endeksten yararlanılmıştır. Düzeltme katsayıları ise, 2013 yılı Aralık ayı endeksinin 2012 yılı Aralık ayı endeksine oranlanması suretiyle hesaplanmıştır. Bu verilere göre XYZ İşletmesinin dönem sonu bilançosunun fiyatlar genel seviyesi muhasebesine göre düzeltilmiş şekli aşağıdaki gibidir;

Tablo 2. XYZ İşletmesinin 31.12.2013 Tarihli Düzeltilmiş Dönem Sonu Bilançosu

\begin{tabular}{|c|c|c|c|c|}
\hline $\begin{array}{c}\text { Geleneksel M } \\
\text { Göre Hesapla }\end{array}$ & $\begin{array}{l}\text { ebeye } \\
\text { Tutar }\end{array}$ & & $\begin{array}{l}\text { Düzeltme } \\
\text { Katsayısı }\end{array}$ & $\begin{array}{l}\text { Fiyatlar Genel } \\
\text { Seviyesi } \\
\text { Muhasebesine }\end{array}$ \\
\hline Kasa & 70.000 & & --- & 70.000 \\
\hline Alınan Çekler & 30.000 & & --- & 30.000 \\
\hline Bankalar & 120.000 & & --- & 120.000 \\
\hline Ticari Mallar & 10.000 & $\mathrm{X}$ & $16.081,9 / 15.033,81$ & 10.697 \\
\hline Binalar & 50.000 & $X$ & $16.081,9 / 15.033,81$ & 53.485 \\
\hline $\begin{array}{l}\text { Tesis Makine } \\
\text { Cihazlar }\end{array}$ & 50.000 & $x$ & $16.081,9 / 15.033,81$ & 53.485 \\
\hline Taşıtlar & 10.000 & $X$ & $16.081,9 / 15.033,81$ & 10.697 \\
\hline $\begin{array}{l}\text { Birikmiş } \\
\text { Amortisman (-) }\end{array}$ & (30.000) & $x$ & $16.081,9 / 15.033,81$ & $(32.091)$ \\
\hline $\begin{array}{l}\text { AKTIF } \\
\text { TOPLAMI }\end{array}$ & 310.000 & & & 316.273 \\
\hline Banka Kredileri & 80.000 & & --- & 80.000 \\
\hline Sermaye & 200.000 & $X$ & $16.081,9 / 15.033,81$ & 213.943 \\
\hline Dönem Karı & 30.000 & & --- & 22.330 \\
\hline $\begin{array}{l}\text { PASİF } \\
\text { TOPLAMI }\end{array}$ & 310.000 & & & 316.273 \\
\hline
\end{tabular}


Geleneksel muhasebe anlayışına göre hesaplanan varlık ve kaynak toplamı ile fiyatlar genel seviyesi muhasebesine göre düzeltme sonrası hesaplanan varlık ve kaynak toplamı arasında 6.273TL (316.273-310.000) fark bulunmaktadır. Bu fark parasal olmayan ticari mallar, binalar, tesis makine cihazlar ve taşıtlar gibi varlık kalemleri ile parasal olmayan sermaye gibi kaynak kalemlerinin fiyatlar genel seviyesi muhasebesine göre düzeltme katsayısı ile cari değerlerinin yeniden hesaplanmasından kaynaklanmaktadır.

XYZ İşletmesinin 2013 yılına ilişkin gelir tablosu (Tablo 3) ile fiyatlar genel seviyesi muhasebesine göre düzeltilmiş gelir tablosu (Tablo 4) aşağıda yer almaktadır;

Tablo 3. XYZ İşletmesinin 31.12.2013 Tarihli Gelir Tablosu

\begin{tabular}{|l|r|}
\hline \multicolumn{2}{|c|}{ 31.12.2013 Tarihli Gelir Tablosu } \\
\hline Brüt Satışlar & 200.000 \\
\hline Satışların Maliyeti & 100.000 \\
\hline Brüt Satış Karı & 100.000 \\
\hline Faaliyet Giderleri & 70.000 \\
\hline Genel Yönetim Giderleri & 10.000 \\
\hline Pazarlama, Satış ve Dağıtım Giderleri & 10.000 \\
\hline Amortisman Giderleri & 50.000 \\
\hline DÖNEM KÂRI & $\mathbf{3 0 . 0 0 0}$ \\
\hline
\end{tabular}


Tablo 4.XYZ İşletmesinin 31.12.2013 Tarihli Düzeltilmiş Gelir Tablosu

\begin{tabular}{|l|c|c|c|c|}
\hline \multicolumn{2}{|c|}{$\begin{array}{l}\text { Geleneksel Muhasebeye } \\
\text { Göre Hesaplanan Tutar }\end{array}$} & \multicolumn{1}{c|}{$\begin{array}{c}\text { Düzeltme } \\
\text { Katsayıs1 }\end{array}$} & $\begin{array}{c}\text { Fiyatlar Genel } \\
\text { Seviyesi } \\
\text { Muhasebesine } \\
\text { Göre Düzeltilen } \\
\text { Tutar }\end{array}$ \\
\hline BRÜT SATIŞLAR & 200.000 & $X$ & $16.081,9 / 15.033,81$ & 213.942 \\
\hline $\begin{array}{l}\text { SATIŞLARIN } \\
\text { MALIYETI }\end{array}$ & 100.000 & $X$ & $16.081,9 / 15.033,81$ & 106.971 \\
\hline $\begin{array}{l}\text { BRÜT SATIŞ } \\
\text { KARI }\end{array}$ & 100.000 & & --- & 106.971 \\
\hline $\begin{array}{l}\text { FAALIYYT } \\
\text { GIDERLERI }\end{array}$ & 70.000 & & --- & 10.697 \\
\hline $\begin{array}{l}\text { Genel Yönetim } \\
\text { Giderleri }\end{array}$ & 10.000 & $X$ & $16.081,9 / 15.033,81$ & 10.697 \\
\hline $\begin{array}{l}\text { Pazarlama Satış } \\
\text { Dağıtım Giderleri }\end{array}$ & 10.000 & $X$ & $16.081,9 / 15.033,81$ & 53.486 \\
\hline $\begin{array}{l}\text { Amortisman } \\
\text { Giderleri }\end{array}$ & 50.000 & $X$ & $16.081,9 / 15.033,81$ & 32.091 \\
\hline DÖNEM KARI & $\mathbf{3 0 . 0 0 0}$ & & --- & 22.330 \\
\hline Enflasyon Kayb1 & & & & \\
\hline $\begin{array}{l}\text { DÖNEM NET } \\
\text { KARI }\end{array}$ & $\mathbf{3 0 . 0 0 0}$ & & & \\
\hline
\end{tabular}

Tablo 4'te görüldüğü üzere geleneksel muhasebeye göre hazırlanan gelir tablosunda XYZ İşletmesi 30.000TL dönem karı elde etmiş olmasına rağmen, fiyatlar genel seviyesi muhasebesine göre düzeltme işlemi sonucu hazırlanan gelir tablosuna göre ise işletmenin dönem karının 22.330TL olduğu tespit edilmiştir. Bu fark parasal olmayan kalemlerin fiyatlar genel seviyesi muhasebesine göre düzeltme katsayısı ile cari değerlerinin yeniden hesaplanmasından kaynaklanmaktadır.

XYZ İşletmesinin parasal kalemlerini elde tutmaktan kaynaklanan enflasyon kazanç ve kayıplarının (net parasal pozisyon) hesaplanması ise aşağıdaki gibidir; 
Tablo 5. XYZ İşletmesinin Düzeltilmiş Finansal Tablolarına Göre Ortaya Çıkan Enflasyon Kaybı

\begin{tabular}{|c|c|c|c|c|}
\hline $\begin{array}{l}\text { Geleneksel Muha } \\
\text { Göre Hesaplanar }\end{array}$ & $\begin{array}{l}\text { ebeye } \\
\text { Tutar }\end{array}$ & & $\begin{array}{l}\text { Düzeltme } \\
\text { Katsayısı }\end{array}$ & $\begin{array}{l}\text { Fiyatlar Genel } \\
\text { Seviyesi } \\
\text { Muhasebesine }\end{array}$ \\
\hline $\begin{array}{l}\text { Dönembaşı parasal } \\
\text { varlıklar toplamı }\end{array}$ & 210.000 & $x$ & $16.081,9 / 15.033,81$ & 224.640 \\
\hline $\begin{array}{l}\text { Dönemiçi parasal } \\
\text { varlıklardaki artış }(+\end{array}$ & & & --- & --- \\
\hline Yurtiçi Satışlar & 200.000 & $x$ & $16.081,9 / 15.033,81$ & 213.943 \\
\hline TOPLAM & 410.000 & & $16.081,9 / 15.033,81$ & 438.583 \\
\hline $\begin{array}{l}\text { Dönemiçi parasal } \\
\text { varlıklardaki azalış ( }\end{array}$ & & & & \\
\hline Ticari Mal Alışı & 150.000 & $\mathrm{x}$ & $16.081,9 / 15.033,81$ & 160.457 \\
\hline $\begin{array}{l}\text { Banka Kredileri } \\
\text { Ödemesi }\end{array}$ & 20.000 & $x$ & $16.081,9 / 15.033,81$ & 21.394 \\
\hline $\begin{array}{l}\text { Pazarlama Satış } \\
\text { Dağıtım G. }\end{array}$ & 10.000 & $\mathrm{x}$ & $16.081,9 / 15.033,81$ & 10.697 \\
\hline $\begin{array}{l}\text { Genel Yönetim } \\
\text { Gideri }\end{array}$ & 10.000 & $x$ & $16.081,9 / 15.033,81$ & 10.697 \\
\hline TOPLAM & 190.000 & & & 203.245 \\
\hline $\begin{array}{l}\text { Dönemsonu } \\
\text { parasal varlıklar } \\
\text { toplamı }\end{array}$ & 220.000 & & & 235.338 \\
\hline $\begin{array}{l}\text { Dönemsonu parasal } \\
\text { toplamı }\end{array}$ & rlıklar & & & 220.000 \\
\hline $\begin{array}{l}\text { Parasal Varlıkları El } \\
\text { Kaybı) }\end{array}$ & Tutma I & Kay & (Enflasyon & $\begin{array}{r}\mathbf{1 5 . 3 3 8} \\
(235.338- \\
220.000) \\
\end{array}$ \\
\hline $\begin{array}{l}\text { Dönembaşı borç } \\
\text { toplamı }\end{array}$ & 100.000 & $x$ & $16.081,9 / 15.033,81$ & 106.971 \\
\hline $\begin{array}{l}\text { Dönembaşı borç } \\
\text { azalışı (-) }\end{array}$ & 20.000 & $x$ & $16.081,9 / 15.033,81$ & 21.394 \\
\hline $\begin{array}{l}\text { Dönemsonu borç } \\
\text { toplamı }\end{array}$ & 80.000 & & & 85.577 \\
\hline Düzeltilmiş Bilançod & & & & 80.000 \\
\hline
\end{tabular}




\begin{tabular}{|l|r|}
\hline Parasal Borçlar Toplamı & \\
\hline Parasal Borçları Elde Tutma Kazancı (Enflasyon & 5.577 \\
Kazancı) & $(85.577-80.000)$ \\
\hline Parasal Değerleri Elde Bulundurma Net Kaybı (Net & $\mathbf{9 . 7 6 1}$ \\
Parasal Pozisyon Zararı) & $(15.338-5.577)$ \\
\hline
\end{tabular}

Tablo 5 'te görüldüğü üzere işletmenin enflasyon ortamında yapmış olduğu düzeltme işlemleri neticesinde parasal değerleri elde bulundurma sonucu ortaya çıkan net parasal pozisyon zararı 9.761TL olarak gerçekleşmiştir.

4.3. Fiyatlar Genel Seviyesi Muhasebesine Göre Finansal Tabloların Düzeltilmesi Neticesi Ortaya Çıkan Sonuçların İşletme Üzerine Etkileri

Enflasyona göre düzeltme öncesi ve düzeltme sonrası ortaya çıan durumun finansal tablolar ve işletme üzerinde birtakım etkileri bulunmaktadır. Bu etkileri aşağıdaki şekilde sıralamak mümkündür;

- Parasal aktif kalemlerin enflasyon ortamında nominal değerleri değişmeyip, satın alma güçleri azalmakta ancak bu satın alma gücü kayıpları gelir tablosuna yansıtılmadığı için dönem kârı gerçekte olduğundan yüksek görünmektedir. Bu da fazla kar dağıtımına ve vergilendirmeye neden olmaktadır. Yapılan çalışmada, düzeltme öncesi hesaplanan 30.000TL tutarındaki dönem karının düzeltme işlemi sonrasında 22.330TL olarak hesaplanması nedeniyle işletme yüksek olan tutar üzerinden kar dağıtımına ve vergilendirmeye tabi tutulma riskiyle karşı karşıya kalmıştır.

- Parasal pasif kalemlerinin de enflasyon ortamında satın alma güçleri azalmaktadır. Bu durum, parasal aktif kalemlerinin tersine parasal pasif kalemlerinin enflasyon ortamında reel değerleri azalacağı için bilançoda gerçek değerlerinin altında izlenmesine neden olduğundan işletmeye ekstra bir kazanç sağlamaktadır. Yapılan çalışmada, işletmenin parasal pasif kalemleri parasal aktif kalemlerinden daha az tutarda olduğu için satın alma gücü kazancı yerine satın alma gücü kaybı, başka bir ifadeyle net parasal pozisyon zararı (9.761TL) yaşanmıştır.

- Parasal olmayan aktif kalemlerinin enflasyon ortamında satın alma güçleri değişmeyip, nominal değerleri değişmektedir. Örneğin tarihi değeriyle kayıtlara alınan maddi duran varlıklar için ayrılan amortisman tutarı enflasyonist dönemlerde daha az olmaktadır. Bunun sonucunda da fiktif kar ortaya çıkarak dönem karı gerçekte 
olduğundan daha yüksek tutarda finansal tablolarda yer almaktadır. Yapılan çalışmada, geleneksel muhasebeye göre maddi duran varlıklar için 30.000TL amortisman ayrılmışken, enflasyon düzeltmesi sonucu bu tutar 32.091TL'ye yükselmiştir. Amortisman tutarının fazla olması, gelir tablosundaki faaliyet karlılığı üzerinde olumsuz bir etki yaratacaktır.

- Parasal olmayan pasif kalemlerinin ise enflasyon ortamında satın alma güçleri değişmeyip, nominal değerleri değişmektedir. Örneğin, özsermaye parasal olmayan kalemlerin finansmanında kullanılmış ise, enflasyon dönemlerinde parasal olmayan varlıkların değeri artacağı için özsermayenin değeri de artmaktadır. Ancak geleneksel muhasebeye göre bu artış hesaplarda görünmemekte ve parasal olmayan aktif ve özsermaye tutarları gerçekte olduğundan daha yüksek tutarda finansal tablolarda yer almaktadır.

Sonuç olarak, parasal aktif kalemleri parasal pasif kalemlerinden fazla olan işletmelerde satın alma gücü kaybı yaşanır ve bu satın alma gücü kaybı gelir tablosuna yansıtılamadığı için dönem karı tutarı olduğundan fazla görünür. $\mathrm{Bu}$ durum, elde edilmemiş olan karın dağıtılmasına veya fazladan vergilendirilmesine yol açmaktadır. Dolayısıyla, işletmenin karını değil sermayesini dağıtmasına neden olmaktadır.

Parasal pasif kalemleri parasal aktif kalemlerinden fazla olan işletmelerde ise satın alma gücü kazancı ortaya çıkar ve dönem karı olduğundan düşük görünür. Bu durumun vergi avantajı gibi olumlu bir etkisinin bulunduğu ifade edilebilirse de, düşük dönem karı nedeniyle işletmenin kredibilitesi olumsuz yönde etkilenebilmektedir. Çalışmadaki örnek işletmede ise, parasal aktif kalemleri parasal pasif kalemlerinden daha fazla tutarda olduğu için enflasyona göre düzeltme işlemi sonucunda net parasal pozisyon zararı ortaya çıkmıştır.

5. TMS 29 Yüksek Enflasyonlu Ekonomilerde Finansal Raporlama Standardı Çerçevesinde Yapılan Düzeltme İşleminin Finansal Analiz Sonuçları Üzerine Etkileri

Geleneksel muhasebeye göre hazırlanan finansal tabloların enflasyonist ortamlarda cari değerlerle gösterilmesi için TMS 29'un önermiş olduğu fiyatlar genel seviyesi muhasebesine göre düzeltilmesi, finansal analiz sonuçları üzerinde de etkili olmaktadır. Çünkü finansal analiz, finansal tablolardaki bilgilerden yararlanılarak yapılmakta ve bu bilgiler düzeltme işlemine tabi tutuldukları için finansal analiz sonuçları da değişiklik göstermektedir. 
Finansal analiz, işletmelerin finansal durumu ile finansal açıdan gelişiminin istenilen düzeyde olup olmadığını tespit etmek amacıyla finansal tablolardaki değişimlerin ve birbiriyle ilişkili kalemlerin zaman içinde göstermiş oldukları değişimlerin incelenmesi ve istenildiğinde daha önceden tespit edilen standart ve sektör ortalaması ile karşılaştırılarak değerlendirilmesi faaliyetleri olarak tanımlanabilmektedir (Çabuk ve Lazol, 2013: 151).

Finansal tabloların analizinde; karşılaştırmalı analiz, dikey analiz, trend analizi ve oran (rasyo) analizi tekniklerinden yararlanılmaktadır. Bu bölümde, finansal tabloların analizinde sıkça başvurulan oran analizi tekniği kullanılarak finansal tabloların analizi gerçekleştirilmiştir.

Oran analizi tekniği, finansal tablolarda bulunan iki kalem arasındaki eğilimlerin matematiksel olarak ifade edilmesi şeklinde tanımlanmaktadır. Bu şekilde hesaplanan oranlar yüzde şeklinde gösterilmektedir. Oran analizinden yararlanırken fazla sayıda oran hesaplamak mümkün ise de, birbiriyle anlamlı ilişki kurulabilecek kalemlere ilişkin oranları hesaplamak daha anlamlı sonuçların ortaya çıkmasını sağlamaktadır (Doğan, 2003: 66).

Oran analizinde yararlanılan likidite oranları, işletmelerin kısa vadeli borçlarını ödeme yeterliliğini tespit etmek amacıyla kullanılırken, işletmenin uzun vadeli borç ödeme gücünün ve varlıkların finansmanında hangi kaynakların kullanıldığının tespit edilmesi için mali yapı oranlarından yararlanılmaktadır. Faaliyet oranları ise, işletmenin faaliyetlerinde kullandığı varlıkların ne düzeyde etkin ve verimli kullanıldığını belirlemek amacıyla kullanılmaktadır. İşletmenin faaliyetleri sonucu ne ölçüde etkin yönetildiğini ve başarısını tespit etmek amacıyla da karlılık oranlarından yararlanılmaktadir.

Yukarıda belirtilen oranlar kullanılarak finansal tabloların analizi yapıldıktan sonra işletmenin durumu hakkında bir karar verebilmek için finansal analiz neticesinde ortaya çıkan sonuçların yorumlanması gerekmektedir. Her oranın yorumlanması kendine özgü nitelikler taşımaktadır. Oran analizi sonucunun yorumlanması sırasında işletmenin finansal durumu ve faaliyet sonuçlarına etkisinin de tespit edilmesi gereklidir. Bunun yanı sıra oranların yorumlanmasında istenilen başarıyı yakalayabilmek için ortaya çıkan sonuçların işletmenin geçmiş faaliyet dönemlerindeki sonuçlar ve sektördeki benzer işletmelerin sonuçlarıyla da karşılaştırılması doğru bir değerlendirme yapılması noktasında büyük önem taşımaktadır.

XYZ İşletmesinin 31.12.2013 tarihli finansal tablolarındaki verilerden yararlanılarak hesaplanan oranların sonuçları Tablo 6' da yer almaktadır. 
Tablo 6. Düzeltme İşleminin Oran Sonuçları Üzerine Etkileri

\begin{tabular}{|c|c|c|c|}
\hline \multicolumn{2}{|c|}{ ORANLAR } & $\begin{array}{c}\text { Geleneksel } \\
\text { Muhasebeye } \\
\text { Göre } \\
\text { Hesaplanan } \\
\text { Tutarlara } \\
\text { İlişkin Oran } \\
\text { Sonuçları }\end{array}$ & $\begin{array}{c}\text { Fiyatlar } \\
\text { Genel } \\
\text { Seviyesine } \\
\text { Göre } \\
\text { Hesaplanan } \\
\text { Tutarlara } \\
\text { İlişkin Oran } \\
\text { Sonuçları }\end{array}$ \\
\hline \multicolumn{4}{|c|}{ LIKİDITTE ORANLARI } \\
\hline Cari Oran & $\begin{array}{c}\text { Dönen Varlıklar/Kısa } \\
\text { Vadeli } \\
\text { Yabancı Kaynaklar } \\
\end{array}$ & 2.87 & 2.88 \\
\hline Asit Test Oranı & $\begin{array}{c}\text { (Dönen varlıklar- } \\
\text { Stoklar)/Kısa } \\
\text { Vadeli Yabancı Kaynaklar } \\
\end{array}$ & 2.75 & 2.75 \\
\hline Nakit Oranı & $\begin{array}{c}\text { (Hazır değerler + Menkul } \\
\text { Kıymetler)/Kısa Vadeli } \\
\text { Yabancı } \\
\text { Kaynaklar }\end{array}$ & 2.75 & 2.75 \\
\hline \multicolumn{4}{|c|}{ MALI YAPI ORANLARI } \\
\hline $\begin{array}{c}\text { Yabancı } \\
\text { Kaynak Oranı }\end{array}$ & $\begin{array}{c}\text { Toplam Yabancı } \\
\text { Kaynaklar/Pasif Toplamı }\end{array}$ & 0.25 & 0.25 \\
\hline $\begin{array}{c}\text { Özkaynak } \\
\text { Oranı }\end{array}$ & $\begin{array}{c}\text { Özkaynaklar/Pasif } \\
\text { Toplamı }\end{array}$ & 0.74 & 0.75 \\
\hline $\begin{array}{c}\text { Yabancı } \\
\text { Kaynakların } \\
\text { Özkaynaklara } \\
\text { Oranı } \\
\end{array}$ & $\begin{array}{l}\text { Toplam Yabanc1 } \\
\text { Kaynaklar/Öz } \\
\text { Kaynaklar }\end{array}$ & 0.34 & 0.33 \\
\hline $\begin{array}{c}\text { Kisa Vadeli } \\
\text { Yabancı } \\
\text { Kaynak Oranı } \\
\end{array}$ & $\begin{array}{c}\text { Kisa Vadeli Yabanc1 } \\
\text { Kaynaklar/Pasif Toplamı }\end{array}$ & 0.25 & 0.25 \\
\hline $\begin{array}{c}\text { Uzun Vadeli } \\
\text { Yabancı } \\
\text { Kaynak Oranı }\end{array}$ & $\begin{array}{c}\text { Uzun Vadeli Yabancı } \\
\text { Kaynaklar/Pasif Toplamı }\end{array}$ & --- & --- \\
\hline \multicolumn{4}{|c|}{ FAALİYET ORANLARI } \\
\hline $\begin{array}{c}\text { Alacak Devir } \\
\text { H1z1 } \\
\end{array}$ & $\begin{array}{l}\text { Net satışlar/Ticari } \\
\text { Alacaklar }\end{array}$ & --- & --- \\
\hline Alacak Tahsil & 365/Alacak Devir Hızı & --- & --- \\
\hline
\end{tabular}




\begin{tabular}{|c|c|c|c|}
\hline Süresi & & & \\
\hline $\begin{array}{c}\text { Stok Devir } \\
\text { H1z1 }\end{array}$ & $\begin{array}{c}\text { Satışların } \\
\text { Maliyeti/Ortalama Stoklar }\end{array}$ & 1.66 & 2.01 \\
\hline $\begin{array}{l}\text { Stok Devir } \\
\text { Süresi }\end{array}$ & 365/Stok Devir Hizı & 219.8 & 181.5 \\
\hline $\begin{array}{c}\text { Aktif Devir } \\
\text { Hiz1 }\end{array}$ & Net Satışlar/Aktif Toplamı & 0.64 & 0.67 \\
\hline \multicolumn{4}{|c|}{ KARLILIK ORANLARI } \\
\hline $\begin{array}{c}\text { Brüt Satış Karı } \\
\text { Oranı }\end{array}$ & Brüt Satış Karı/Net Satışlar & 0.50 & 0.49 \\
\hline $\begin{array}{c}\text { Faaliyet Karı } \\
\text { Oranı }\end{array}$ & Faaliyet Karı/Net Satışlar & 0.15 & 0.15 \\
\hline $\begin{array}{c}\text { Dönem Net } \\
\text { Karı Oranı }\end{array}$ & $\begin{array}{c}\text { Dönem Net Karı/Net } \\
\text { Satışlar } \\
\end{array}$ & 0.15 & 0.10 \\
\hline $\begin{array}{c}\text { Aktif Karlılık } \\
\text { Oranı }\end{array}$ & Dönem Karı/Aktif Toplamı & 0.09 & 0.10 \\
\hline
\end{tabular}

Tablo 6'da görüldügüü üzere, geleneksel muhasebe ve fiyatlar genel seviyesi muhasebesine göre hazırlanan finansal tablolar üzerinde yapılan analiz neticesinde ortaya çıkan likidite oranlarına ilişkin sonuçlar incelendiğinde, cari oran sonuçlarındaki çok küçük bir değişiklik dışında bir farklılık bulunmamaktadır. Cari oranda farklılık olmasının nedeni cari oran hesaplamasında dikkate alınan parasal olmayan stoklar kaleminin fiyatlar genel seviyesi muhasebesine göre endeks yardımıyla düzeltilmiş olmasıdır.

Mali yapı oranlarına ilişkin sonuçlar incelendiğinde, özkaynak oranı ve yabancı kaynakların özkaynaklara oranına ilişkin sonuçlar haricinde bir farklılık bulunmamaktadır. Bu oranlarda farklılık ortaya çıkması, hesaplamalarda dikkate alınan özkaynaklar içerisindeki parasal olmayan sermaye kalemi ile gelir tablosundaki satışlara ilişkin parasal olmayan kalemlerin fiyatlar genel seviyesi muhasebesine göre endeks yardımıyla düzeltilmesinden kaynaklanmaktadır. Bu bölümde, bilançoda uzun vadeli yabancı kaynaklar bölümü bulunmadığı için uzun vadeli yabancı kaynak oranı hesaplanamamıştır.

Faaliyet oranlarına ilişkin sonuçlar incelendiğinde, aktif devir hızı oranı, stok devir hızı oranı ve stok devir süresi oranı sonuçlarında farklılık bulunmaktadır. Aktif devir hızı oranında farklılık ortaya çıkması, hesaplamalarda dikkate alınan aktif yapı içindeki parasal olmayan stoklar ve maddi duran varlıkların endeks yardımıla düzeltilmesinden kaynaklanmaktadır. Stok devir hızı oranında farklılık olmasının nedeni ise 
parasal olmayan stokların endeks yardımıyla düzeltilmiş olmasıdır. Stok devir hızının artışına bağlı olarak bu oranla ters yönde hareket eden stok devir süresinde azalış meydana gelmiştir. Bu bölümde, bilançoda ticari alacaklar bölümü bulunmadığı için alacak devir hızı ve alacak devir süresi hesaplanamamıştır.

Karlılık oranları incelendiğinde, faaliyet karı oranı sonucu haricinde bütün oranlarda farklılık bulunmaktadır. Brüt satış karı oranına ilişkin sonuçların farklılık göstermesinin nedeni, satışlara ilişkin parasal olmayan kalemlerin endeks yardımıyla düzeltilmiş olmasıdır. Dönem net karı oranına ilişkin sonuçların farklılık göstermesinin nedeni, satışlar içerisindeki kalemlerin endeks yardımıyla düzeltilmesidir. Aktif karlılık oranı sonucunda farklılık ortaya çıkmasının nedeni ise, gelir tablosundaki satışlara ilişkin parasal olmayan kalemler ile aktif yapı içerisindeki parasal olmayan kalemlerin fiyatlar genel seviyesi muhasebesine göre endeks yardımıla düzeltilmiş olmasıdır.

Sonuç olarak, geleneksel muhasebe ve fiyatlar genel seviyesi muhasebesine göre hazırlanan finansal tablo kalemlerinde yapılan finansal analiz sonuçlarında küçük de olsa farklılıklar oluşmuştur. Bu farklılıkların finansal tabloların enflasyona göre düzeltilmesine bağlı olarak ortaya çıktığı tespit edilmiştir.

\section{Sonuç}

Enflasyonun yüksek olduğu dönemlerde finansal tablolarda yer alan parasal kalemler dışındaki kalemler cari dönemdeki satın alma güçlerini göstermemektedir. Bu kalemlerin cari satın alma güçlerini yansıtacak şekilde düzeltilmesi, işletmelerin finansal durumu ve faaliyet sonuçlarının doğru bir şekilde yorumlanması bakımından önem arz etmektedir.

Enflasyonun etkileri dikkate alınmadan hazırlanan finansal tablolar finansal bilgi kullanıcılarına yanıltıcı bilgi sundukları için bu kişilerin yanlış karar almalarına neden olmaktadır. Bu nedenle finansal bilgi kullanıcılarının doğru karar almalarına yardımcı olabilecek bilgiler sunulması önemlidir. Bundan dolayı enflasyonun finansal tablolar üzerindeki etkilerinin çeşitli düzeltme yöntemleri kullanılmak suretiyle giderilmesi gerekmektedir. Enflasyonun finansal tablolar üzerindeki etkilerinin giderilmesine yönelik vergi mevzuatında bazı düzeltme yöntemleri bulunmasına rağmen bu düzeltme yöntemleri, yüksek düzeyde gerçekleşen ve uzun süreli olan enflasyon karşısında yeterli olmamaktadır.

$\mathrm{Bu}$ çalışmada enflasyonun finansal tablolar üzerindeki etkisinin giderilmesi amaciyla enflasyon muhasebesi yöntemlerinden fiyatlar genel seviyesi muhasebesine göre enflasyon düzeltmesi yapılmıştır. Geleneksel 
Sosyal Bilimler Dergisi 51

finansal tabloların fiyatlar genel seviyesi muhasebesine göre düzeltilmesi sonucu finansal tablolarda önemli sayılabilecek değişiklikler meydana gelmiştir. Düzeltme öncesi finansal tablo verileri ile düzeltme sonrası finansal tablo verileri arasında ortaya çıkan farklılıkların, hem işletme hem de finansal analiz sonuçları üzerine etkileri ortaya konulmuştur.

Sonuç olarak, yüksek enflasyonlu dönemlerde fiyatlar genel seviyesi muhasebesine göre finansal tabloların düzeltilmesi, daha gerçekçi bilgiler elde edilmesini sağlamakta ve böylece finansal bilgi kullanıcılarının alacakları kararların doğru ve güvenilir olmasına yardımcı olmaktadır.

\section{Kaynakça}

AÇIK, S. (2006), “Enflasyonun Finansal Tablolar Üzerindeki Etkilerini Giderici Bir Tedbir Olarak Enflasyon Muhasebesi ve Türkiye'deki Yasal Düzenlemeler", Atatürk Üniversitesi Sosyal Bilimler Enstitüsü Dergisi, Sayı: 8 (2).

AKDOĞAN, N. ve TENKER, N.(2001), "Finansal Tablolar ve Mali Analiz Teknikleri", Ankara: Gazi Kitabevi.

ALTINIŞIK, İ. (2004), "Enflasyonun İşletmeler Üzerindeki Etkisi ve Bu Etkileri Gidermeye Yönelik Yöntemler", Selçuk Üniversitesi Sosyal Bilimler Meslek Yüksekokulu Dergisi, Cilt: 7, Sayı: 1-2.

AKTAŞ, S. (2006), "Enflasyon Muhasebesinin Mali Tablolara Etkisi ve Türkiye'de Yıllara Sari İnşaat İşletmelerinde Enflasyon Düzeltmesi Uygulaması", Yüksek Lisans Tezi, Marmara Üniversitesi, Sosyal Bilimler Enstitüsü.

ÇABUK, A. ve LAZOL, İ.(2013), "Mali Tablolar Analizi", Bursa: Ekin Basım Yayın Dağıtım.

ÇELIK, A. (2003), "Fiyatlar Seviyesindeki Değişmelerin Mali Tablolara Etkileri ve Enflasyon Muhasebesi: Enflasyon Muhasebesi Yöntemlerinden Fiyatlar Genel Seviyesi Modeli Uygulaması", Uzmanlık Tezi, Merkez Bankası.

DOĞAN, Z. (2003), “Çeviri Yöntemlerinin Mali Analiz Sonuçları Üzerindeki Etkisi", Uludă̆ Üniversitesi İktisadi ve İdari Bilimler Fakültesi Dergisi, Cilt: 22, Sayı: 2.

GÜCENME, Ü. (1996), "Mali Tablolar Analizi", Bursa: Marmara Kitabevi yayınları.

İLERİ, H. ve ALTINIŞIK, İ.(2004), “Enflasyon Düzeltmesinin Gerekliliği, Enflasyon Muhasebesinin Uygulanabilirliği ve Muhasebeciler Üzerinde Yapılan Bir Araştırma: Karaman Örneği", Selçuk Üniversitesi Sosyal Bilimler Meslek Yüksekokulu Dergisi, C: 7, Sayı: 1-2. 
KAYGUSUZ, M. (2001), “Maliyet Enflasyonu ve Türkiye'de Maliyet Enflasyonunun Nedenleri" http://www.ceterisparibus.net/arsiv/ mkaykusuz2.doc, (Erişim Tarihi: 22.11.2014).

OSMAN, Z. O. (1995), "Enflasyon Teorileri ve İstikrar Politikaları", İstanbul: Filiz Kitabevi.

ÖZDEMIR, F. S. ve ARSLAN, S.(2007), "Enflasyon Muhasebesinde Kullanılan Yöntemlerin Karşılaştırmalı Analizi", Ticaret ve Turizm Ĕ̆itim Fakültesi Dergisi, Sayı: 2.

ÖZULUCAN, A. (2002a), “Enflasyonun Muhasebe Verileri Üzerindeki Etkisinin Giderilmesinde Kullanılan Oto Finansman Yöntemleri ve Enflasyon Muhasebesi Üzerine Bir Araştırma", Ankara Üniversitesi Siyasal Bilgiler Fakültesi Dergisi, Sayı: 57-4.

ÖZULUCAN, A. (2002b), “Enflasyonun Muhasebe Verileri Üzerindeki Etkileri, Türkiye Muhasebe Standard 2 ve Sermaye Piyasası Kurulu Seri: XI-No:20 Çerçevesinde Önerilen Enflasyon Muhasebesi Yöntemi ve Enflasyon Muhasebesine Geçişte Alınabilecek Önlemler", Celal Bayar Üniversitesi İ̈BF Dergisi, Cilt: 9, Sayı: 1-2.

TMS 29: Yüksek Enflasyonlu Ekonomilerde Finansal Raporlama Standardı.

TÜIK, Toptan Eşya Fiyat Endeksleri, http://www.tuik.gov.tr/PreTablo.do?alt_id=1076 (Erişim Tarihi: 04.05.2015).

USLU, O. (2003), "Genel Hatlariyla Enflasyon Muhasebesi", https://www.alomaliye.com/ozan_uslu_enflasyon_muhasebesi.htm, (Erişim Tarihi: 22.11.2014).

YAVUZ, G. (2007), “Enflasyon Muhasebesi ve Bir Uygulama”, Doktora Tezi, Kocaeli Üniversitesi, Sosyal Bilimler Enstitüsü.

YÜKSEL, A. (1997), “Enflasyon Muhasebesi”, İstanbul: Literatür Yayınları. 